\title{
LUT
}

University

Freelancing on digital work platforms - roles of virtual community trust and work engagement on person-job fit

Toth Ilona, Heinänen Sanna, Blomqvist Kirsimarja

This is a Final draft

version of a publication

published by Emerald Publishing

in VINE Journal of Information and Knowledge Management Systems

DOI: $10.1108 /$ VJIKMS-12-2018-0124

Copyright of the original publication: (c) Emerald Publishing 2020

Please cite the publication as follows:

Toth, I., Heinänen, S., Blomqvist, K. (2020). Freelancing on digital work platforms - roles of virtual community trust and work engagement on person-job fit. VINE Journal of Information and Knowledge Management Systems. DOI: 10.1108/VJIKMS-12-2018-0124

This is a parallel published version of an original publication.

This version can differ from the original published article. 
VINE Journal of Information and Knowledge Manag

\section{Freelancing on digital work platforms - Roles of virtual community trust and work engagement on person-job fit}

\begin{tabular}{|r|l|}
\hline Journal: & VINE Journal of Information and Knowledge Management Systems \\
\hline Manuscript ID & VJIKMS-12-2018-0124.R1 \\
\hline Manuscript Type: & Research Paper \\
\hline Keywords: & $\begin{array}{l}\text { knowledge workers, freelancing, digital work platform, virtual community } \\
\text { trust, work engagement, person-job fit }\end{array}$ \\
\hline \multicolumn{2}{|l}{} \\
\hline
\end{tabular}

SCHOLARONE ${ }^{\text {m }}$

Manuscripts 


\section{Freelancing on digital work platforms - Roles of virtual community trust and work engagement on person-job fit}

\section{Abstract \\ Purpose}

The purpose of this paper is to investigate the impact of virtual community trust on work engagement and person-job fit in the context of digital work platforms. The emergence of the platform economy is changing the work environment fundamentally. It has enabled the appearance of alternative work arrangements, such as temporary organizing and the increase of independent contracting, also among highly specialized knowledge workers.

\section{Design/methodology/approach}

Data was collected with an online survey and used to test the relationships between virtual community trust, work engagement and person-job fit. Confirmatory factor analysis and structural equation modelling were used to test the goodness of a theoretical model.

\section{Findings}

Based on the data of 127 experts contracting on digital work platforms, virtual community trust positively affects both work engagement and person-job fit. In addition, the relationship between work engagement and person-job fit in the context of digital work platforms is significant and positive.

\section{Practical implications}

This study shows that trust among independent contractors working on digital platforms is important for work engagement, and that platform providers can improve work performance through person-job fit by assisting in the creation of trust among members of their platforms.

\section{Originality/value}

Research literature on knowledge work in the changing context of work is scarce, and the role of trust in the context of digital work platforms needs clarification. This paper tests a theoretical model on the effects of trust among highly skilled experts working in the digital platform context as independent 
contractors, and provides evidence for the importance of building trust among members of a virtual work community.

Keywords Knowledge workers, Freelancing, Digital work platform, Virtual community trust, Work engagement, Person-job fit

Paper type Research paper 


\section{Introduction}

Knowledge work is currently undergoing several significant changes. The emergence of the platform economy (Caballer, Gracia and Peiró, 2016), an increasing number of freelancing in highly complex expert work (Turner and Pennington, 2015), and various forms of temporary organizing (Aguinis and Lawal, 2013; Spinuzzi, 2012), are leading to a shift from steady traditional work relationships to increased heterogeneity of work relationships and related tasks (Sullivan, Forret, Mainiero and Terjesen, 2007), as well as ways of doing them. Current technological and socio-economical changes lower job stability and may also challenge understanding of person-job fit as a psychological state (Edwards, 2008).

Global competition, constant demand for innovation and a tendency towards organizing work in projects and assigning teams to work tasks have made the world of work more fast-paced and demanding (Turner and Pennington, 2015). For employees there is a continuous demand for expanding their knowledge base, building social networks, and participating in competition. This trend has further been strengthened by the increase of virtual work, which means that work is no longer tied to an office location and office hours, which results in blurring the boundary between work and private life. (van Beek, Hu, Schaufeli, Taris and Schreurs, 2012.)

For knowledge workers this is a challenging position as these highly skilled experts are expected to align and identify with an organization while at the same time being flexible and ready for change (Kelliher and Richardson, 2011). The focus of employability is on individual skills and competences which are needed both at the technical and social level, i.e. co-operation with colleagues, superiors, and customers (Süß and Becker, 2013).

One of the new business trends enabled by digitalization is the so-called platform economy, which means benefiting from a set of online digital arrangements in organizing and structuring economic and social activities. Platform economy means changing radically the way we work, socialize, and create value. Platforms can mediate work in many ways including transformations from independent knowledge work to crowdsourcing (i.e. dividing work between participants for cumulative results) and by transforming traditional work into tasks which can be performed by contractors, or even creating entirely new categories of work and entrepreneurial opportunities. Theoretical contributions about the effects of these platforms on the global economy are still scarce. (Kenney and Zysman, 2016.)

From the work engagement perspective, the importance of organizational culture and talent development along with trust building are emphasized in the context of new work. Building trust translates to other 
values such as empowering employees to take charge of their own career development and driving new knowledge creation through workplace practices. (Kane, Palmer, Nguyen Phillips, Kiron and Buckley, 2016.) There is also a need to understand what happens to work engagement outside traditional organizational settings (Spreitzer, Cameron and Garrett, 2017).

"Independent contractors are defined as self-employed individuals who contract or sell their services to a client organization on a fixed term or project basis" (Aguinis and Lawal, 2013, 8). Boundaryless knowledge workers choose self-employment for various reasons, the most commonly mentioned of which are issues in relation to autonomy, flexibility, and work life balance (Van den Born and Van Witteloostuijn, 2013). These high-skill professionals who engage in freelance contract work are clearly distinguishable from traditional temporary workers, as their preference for short-term contracting is often voluntary and they have continuously reported positive outcomes about job and career satisfaction (Van den Born and Van Witteloostuijn, 2013).

Based on the ongoing academic and popular discussion on digitalization and the future of work, it is of interest to explore the relationship between virtual community trust, work engagement, and person-job fit. Despite increased freedom and flexibility, freelancers seek for social support in their work to reduce stress caused by work demands (García-Herrero, Mariscal, Gutiérrez and Ritzel, 2013).

Spreitzer et al. (2017) classify people who engage in alternative work arrangements as belonging to three different groups: high-skill freelancers who prefer work-life flexibility, permanent employees who choose to work extra, and low-wage service workers. The first two classes correspond to the research settings in this study, as the data was collected from the context of digital work platforms where knowledge workers are not employed but paid by assignment. A theoretical research model is built where person-job fit is affected by both virtual community trust and the experience of work engagement. The sample consists of 127 experts working on digital work platforms on contractual basis. Respondents represent two different organizations arranging their work tasks through digital work platforms. One organization is based on the idea of co-creation where complex problem solving tasks are assigned for temporary project teams composed of members of a large expert community. The other organization offers autonomous expert services where clients submit task requests online and the organization assigns suitable freelancers from their community.

The article is structured as follows. We first present theoretical foundations for the three major concepts in our study, that is, work engagement, person-job fit and virtual community trust in chapter 2 . We then proceed to describing the research settings and methodology used in chapter 3, which is followed by chapter 4 reporting our research results. Chapter 5 discusses our findings together with their theoretical 
implications and managerial contribution. The article ends with our conclusions, which are made in chapter 6.

\section{Theoretical foundation and hypotheses development}

\subsection{Virtual community trust}

Prior research emphasizes the role of trust both in organizational and interest-based virtual communities (Kosonen, Blomqvist and Ellonen, 2008; Kosonen, 2009). "Virtual communities can be defined as groups of people with common interests and practices that communicate regularly and for some duration in an organized way over the Internet through a common location or mechanism” (Ridings, Gefen and Arinze, 2002, 273). Their role has been suggested to become increasingly important in digital platforms (Faraj, von Krogh, Monteiro and Lakhani, 2016) that offer individuals temporary work without monthly pay and long-term commitment. Individuals working as freelancers do not have a supervisor and collegial support available in traditional organizations. In this type of unstructured organizational context, trust becomes quintessential (Dirks and Ferrin, 2001) enhancing individual positive expectations and willingness to accept vulnerability and risks embedded (Blomqvist, 1997).

In past research, trust has been defined as "the willingness of a party to be vulnerable to the actions of another party based on the expectations that the other will perform a particular action important to the trustor, irrespective of the ability to monitor or control the other party" (Mayer, Davis and Schoorman, 1995). According to this widely used conceptualization, trust is a multi-dimensional construct consisting of ability, benevolence and integrity. We adopt this definition and the Trusting Beliefs Scale measure developed for the e-commerce context by McKnight, Choudbury and Kacmar (2002) and further applied in the virtual community context by Usoro, Sharrat, Tsui and Shekhar (2007).

Much of the past research on virtual community trust has focused in information and knowledge sharing (Ridings et al., 2002; Hsu, Ju, Yen and Chang, 2007; Chen and Hung, 2010; Majewski, Usoro and Khan, 2011) yet there can be other less studied benefits. In the organizational context trust has been shown to generate positive outcomes in employee attitudes, perception, behavior and performance (Dirks and Ferrin, 2001) such as job satisfaction (Rich, 1997), enhanced effort (Dirks, 1999), and task performance (Oldham, 1975).

Despite the extensive research on organizational and virtual community context, the research on freelancer trust in digital work platforms is still scarce, if not non-existing. In this specific context, virtual 
community trust may be critical in substituting supervisor, team and organizational structures available in traditional organizations (Faraj et al., 2016) and providing the much needed supporting social context for freelancers (Colbert, Yee and George, 2016; Heaphy, Byron, Ballinger, Gittell, Leana and Sluss, 2018).

\subsection{Work engagement}

Work engagement has been identified as one of the most significant drivers for positive work performance (Rich, Lepine and Crawford, 2010). It is a psychological state, which consists of physical, emotional, and cognitive behavioral aspects (Kahn 1990; 1992) of work. It has been defined as " $a$ desirable condition, [which] has an organizational purpose, and connotes involvement, commitment, passion, enthusiasm, focused effort, and energy" (Macey and Schneider, 2008, 4) and as "a positive, fulfilling work-related state of mind that is characterized by vigor, dedication, and absorption" (Schaufeli, Salanova, González-Roma and Bakker 2002, 74). Work engagement is thus strongly connected to meaningful work (Macey and Schneider, 2008) which is directly related to the significance of work as well as positive valence (Steger, Dik and Duffy, 2012).

The history of the work engagement concept lies in the positive psychology movement originated by Seligman and Csikszentmihalyi (2000) during the early $21^{\text {st }}$ century, as research on human behavior and motivation had earlier been strongly orientated towards negative theories and finding remedies for negative states, such as burnout. The rise of positive psychology has led to an interest in work-related well-being and the emergence of a new work-related concept, i.e. work engagement. Work engagement is closely related to other concepts, which show positive orientation towards work, such as organizational commitment, job satisfaction, and job involvement. However, several researchers (Saks and Gruman, 2014, Rich et al., 2010; Hallberg and Schaufeli, 2006) have argued towards work engagement's originality as a concept, and provide convincing evidence as to the status of work engagement as an independent concept, separate from burnout (Schaufeli and Salanova, 2007) and workaholism (Mäkikangas, Schaufeli, Tolvanen and Feldt, 2013).

The work-related engagement construct relies on the Job Demands-Resources Model created by Demerouti, Bakker, Nachreiner and Schaufeli in 2001, which can also be used as an alternative way for measuring employee well-being. The Job Demands-Resources model is a heuristic model specifying how employee well-being can be produced by two sets of working conditions. Job demands are characteristics of the job, which can evoke strain if they exceed the employee's adaptive capability, and job resources are working conditions, which the job at hand offers to individual employees. The basic idea behind the model is thus that while job demands can lead to exhausting employees' physical and 
mental resources, job resources are motivational and can lead to positive attitudes, behavior, and wellbeing.

It has been established in several studies (e.g. Bakker, Albrecht and Leiter, 2011; Edwards, 2008) that increased work engagement leads to a better person-job fit. We believe that work engagement is especially critical for person-job fit in new forms of organizing knowledge work (Sullivan et al., 2007), such as digital work platforms where work is done on contractual basis by independent freelancers. Thus, we aim to clarify the relationship between virtual community trust, work engagement and person-job fit in the context of temporary digital platform work.

\subsection{Person-job fit}

We draw on the past research on person-job fit (Edwards, 2008; Kristof-Brown, Zimmerman and Johnson, 2005) which describes a match between personal abilities and demands of the job (Cable and Judge, 1996; Lauver and Kristof-Brown, 2001). Person-job fit is part of a larger framework of personenvironment fit relationships. A meta-analysis conducted by Kristof-Brown et al. (2005) identifies four types of person-environment fit relationships in work contexts. These are person-job fit, personorganization fit, person-group fit, and person-supervisor fit. Especially the first two have been most extensive studied by researchers (Sekiguchi, 2004).

Resick, Baltes, and Shantz (2007) have defined job fit as the degree to which a person feels that his/her personality meets with the values of the current job. Whereas person-organization fit emphasizes the compatibility between an employee and the organization (Sekiguchi, 2004), person-job fit focuses on the match between personal characteristics and job characteristics (Resick et al., 2007). Researchers who have studied person-job fit suggest that it provides possibilities for individually meaningful work (Shuck, Reio, and Rocco, 2011) which together with trust and value congruence (Siebert, Martin, and Bozic, 2016) is an important antecedent to work engagement.

According to past research, person-job fit leads to job satisfaction (Latham and Pinder, 2005), and is also related to beneficial organizational results (Tims and Bakker, 2010; Edwards, 2008). Person-job fit is an important factor in recruitment processes where the individual's knowledge, skills and abilities need to be considered in relation to the demands of the job description (Edwards, 2008). In addition to the fit between personal abilities and demands of the job, person-job fit also deals with employees' needs and preferences towards the work tasks that they perform. This type of person-job fit concerns the needssupplies and/or supplies-values fit (Kristof-Brown, et al., 2005.) 


\subsection{Hypotheses}

For the freelancers working on temporary tasks on digital work platforms the person-job fit may be relatively more important than the fit in person-team, person-supervisor, or person-organization. Based on research on the positive organizational (Dirks and Ferrin, 2001) and virtual community outcomes (Ridings et al., 2002) we assume that trust can have a positive impact on person-job fit by enhancing freelancer job-related positive attitudes, motivation and performance. Likewise, based on past scarce research on the relationship of trust and work engagement (Chughtai and Buckley, 2008; Agarwal, 2014) we expect that virtual community trust can have a positive impact on individual work engagement on digital work platforms. Therefore, we seek to clarify the relationships between virtual community trust and work engagement, as well as the relationship between virtual community trust and person-job fit in the context of temporary work on digital platforms. Thus, we hypothesize that:

H1 Virtual community trust is positively related to work engagement

H2 Virtual community trust is positively related to person-job fit

H3 Work engagement is positively related to person-job fit

\subsection{Research model}

The connection between trust and work engagement has previously been studied by e.g. Macey and Schneider (2008) and by Sharkie (2009). Chucktai and Buckley (2008) have established a mutually reinforcing relationship between trust and work engagement, which can lead to a positive spiral effect. Finally, experience-driven communities have shown to generate trust and engagement (Hsu et al., 2012). By experience-driven communities we mean the community-based experiences where value is delivered through reciprocal bonding (Hsu et al., 2012). The simultaneous effects of virtual community trust and that of work engagement to person-job fit have not been previously studied in the context of virtual knowledge work. We expect that the relationship between virtual community trust and work engagement is positive and that virtual community trust further intensifies the relationship between work engagement and person-job fit. Our research model is presented in Figure 1 below.

$<<<$ Please insert Figure 1 about here $>>>$ 


\section{Methodology}

\subsection{Sample and procedure}

The data was collected in March 2018 with an online questionnaire sent to experts working for two digital work platforms. The headquarters of the organizations are based in Finland but both contract experts around the world. The sample consists of experts who had joined the platform organization either before May 2017 or within a year. The survey was open for three weeks during which time 227 persons answered the questionnaire.

Out of the 227 respondents, $57.6 \%$ were male, and $42.4 \%$ were female. A clear majority of the respondents, $70.3 \%$, were between $25-44$ years of age. $35.0 \%$ of the respondents were Finnish, while $65.0 \%$ of the respondents were of mixed nationalities. Roughly half of the respondents (44.5\%) said they had a bachelor or a master level university education. Rest of the respondents did not wish to state their educational background. Due to missing values in responses, the effective sample size was 127 responses.

\subsection{Measures}

We used a well-constructed and validated scale for measuring virtual community trust; that is Usoro et al.'s (2007) Virtual community trust measure, which consists of 12 items. We followed the principles by Heggestad, Sheaf, Banks, Monroe Hausfeld, Tonidandel and Williams (2019) and ensured its content validity by pre-testing the measure in the freelancer context. WE also used Schaufeli, Bakker and Salanova's (2006) shortened version of the Work and Well-being Survey UWES (Utrech Work Engagement Scale) which consists of 9 items, and Kristof-Brown et al.'s (2005) Person-job fit measure which consists of five items, to test our hypotheses. Examples of measuring items are "The community is truthful in its dealings with me." or "The community would keep its commitments." for virtual community trust; "I am enthusiastic about my job." or "I get carried away when I'm working." for work engagement; and "To what extent does working in XYZ's projects fit with your expectations?" for PJF. The question formatting was based on the Likert scale with 1 equaling 'Strongly disagree' or 'Never', to 7 equaling 'Strongly agree' or 'Always', as the extreme ends of the scale. We used Structural Equation Modelling (SEM) with LISREL to test the goodness of our research model.

The data included incomplete responses with various frequencies of missing values. Multiple imputation was conducted only for cases that had missing values for less than 50 percent per measured concept. This resulted in an effective sample of 127 responses. 


\section{Results}

\subsection{Measurement model validation}

Confirmatory factor analysis was conducted in order to verify the measurement of the key concepts used in the present study. Maximum likelihood estimation was applied with LISREL assuming the variables to be continuous. Some modifications were necessary although the measurement items were based on previously validated items. The short scale for measuring engagement (UWES-9) was shortened to include only two items for each of the latent dimensions. In addition, one item was dropped from the person job fit scale. Virtual community trust originally included twelve items expected to load on three latent dimension. Three items were dropped due to low loadings and misfit leading to the conclusion that the latent dimensions of benevolence, integrity and competence were each measured with three items. With these changes, the model fit meets the standards for good fit allowing further analysis (Table $1)$.

$<<<$ Please insert Table 1 about here $>>>$

\subsection{Hypotheses testing}

The hypotheses were tested using maximum likelihood estimation with LISREL. For the purpose of modelling the structural research model, the measurement of work engagement included summated scales computed based on the results of the confirmatory factor analysis. This means that work engagement will further on be reflected with three indicators (vigor, dedication, absorption). Each of these were computed mean values of the indicators accepted in the measurement model analysis. A similar manner was applied for virtual community trust and its dimensions. This principal and the results of the modelling are presented in Figure 2.

$<<<$ Please insert Figure 2 about here $>>>$ 
Model itself provided adequate level of fit $\left(\chi^{2}=58.47, \mathrm{df}=32, \mathrm{RMSEA}=0.081, \mathrm{NFI}=0.957, \mathrm{NNFI}=0.968\right)$.

While considering the structure of the model itself, all paths appeared to be highly significant $(\mathrm{p}<.001)$. The first hypothesis discussed the relationship between virtual community trust and work engagement. It seems that virtual community trust has a positive influence on work engagement as proposed. However, the explanatory power is naturally quite low as virtual community trust explains only 12.4 percent of the variation in work engagement.

The second hypothesis suggested that virtual community trust has a positive influence on person job fit. Based on the results, this hypothesis is supported with a positive and statistically significant path coefficient. The third and final hypothesis concerned the relationship between work engagement and person job fit and is accepted based on the results. The resulting path coefficient has the highest absolute value in the model indicating that there exists a strong positive relationship between these two constructs. The overall $\mathrm{R}$ square for person job fit was 0.564 , which means that virtual community trust and work engagement together have a high explanatory power on person job fit.

\section{Discussion}

In response to a growing interest on the changing context of knowledge work and the increase of alternative work arrangements (Spreitzer et al., 2017), the present study emphasizes the importance of virtual community trust on the development of both the experience of work engagement and person-job fit in the digital work platform context. Previously, Agarwal (2014) has studied the relationship between justice, trust and innovative work behavior to work engagement. However to our knowledge, research linking trust and work engagement in digital work platform is currently non-existent.

The positive connection between work engagement and person-job fit has been established in several studies (e.g. Bakker et al., 2011; Edwards, 2008) but as far as we know the simultaneous effect of both virtual community trust and work engagement on person-job fit has not been previously investigated.

\subsection{Theoretical implications}

Our contribution to existing research literature is significant as a growing number of employees can be classified as knowledge workers. By knowledge workers we mean employees who use knowledge for higher productivity and performance (Davenport, Thomas, Cantrell and De Long, 2002; Nickols, 2000; Dul, Ceylan and Jaspers, 2011) either as independent contractors or as employees in organizations. 
May, Gilson, and Harter (2004) state that people seek out work roles that allow them to behave in a way that expresses their authentic self-concepts. This finding is align with our research model as our purpose was to evaluate whether an expert's idea of meaningful work fits with the characteristics of temporary project work offered on the digital platform. Sortheix, Chow, and Salmela-Aro (2015) have used KristofBrown et al.'s Person-Job Fit scale as an outcome measure in their longitudinal study on work values and the transition to work life. Our study adds to this research by showing the positive connection between virtual community trust and work engagement to person-job fit. Finally, Christian, Garza, and Slaughter (2011) have suggested that engaged workers may develop a stronger sense of fit to the job or to the environment. Our study confirms this suggestion by showing a positive effect of work engagement on person-job fit.

Dedicated and reliable contractors are the most important asset when digital work platform providers build their competitive advantage. Our study adds to previous studies as it shows a significant positive relationship between virtual community trust and work engagement as well as between virtual community trust and person-job fit.

Person-job fit and task-technology fit are complementary concepts that measure effectiveness in work conditions which further lead to better work performance. The role of task-technology fit in knowledge creation has earlier been discussed by Wu, Kao and Shih (2018). This study adds to previous research by showing the positive connection between trust and person-job fit. It can be argued that the importance of both types of fit becomes crucial in the context of digital work platforms where task-technology fit is needed for effective working (Wu et al., 2018) and person-job fit for task performance (Chi and Pan, 2012).

The present study contributes to the research literature on work engagement and corroborates the positive relationship between work engagement and person-job fit also in the digital work platform context, which is shaped by an increase of autonomy and temporariness. It can be argued that the role of personjob fit is intensified in the context of temporary contracting on digital work platforms as the roles of person-organization fit and person-supervisor fit are less relevant in this work context. The positive relationship between work engagement and person-job fit has to our knowledge previously been established only in traditional organizational settings.

\subsection{Managerial contribution}

For digital work platform provides, building a virtual community where independent contractors feel safe to contribute is of crucial importance. Our study indicates that digital work platform providers need 
to be aware of the challenges and possibilities in building trust in their virtual communities, and assist in its creation as it leads to positive performance results, such as work engagement and person-job fit. Significant elements in trust building are for example truthfulness and fairness in operational issues and always acting in the best interests of members contributing to the digital work platform functions.

\subsection{Limitations and future research directions}

As with all studies, also this study has some limitations. The measure used for virtual community trust (Usoro et al., 2007) has been developed to study trust in e-commerce and adapted to knowledge sharing in an intra-organizational virtual community. However, we further adapted the items to suit our study context and tested them with study subjects.

We also need more understanding on the relationship between nature of work and personal abilities, that is between job characteristics and personal characteristics (Resick et al., 2007), in the context of digital platform work. Past research on the relationship between trust and work engagement suggests it may be mutually reinforcing (Chughtai and Buckley, 2008; Agarwal, 2014). Our study was cross-sectional so we can only show their positive relationship and suggest that further longitudinal studies would be needed to judge their causality.

It seems that research on independent knowledge work is scarce, and we suggest placing more emphasis on research in various forms of contemporary knowledge work. Goodhue (1998) has earlier used tasktechnology fit to explain how technology leads to individuals' positive performance impacts. In the future, it would be interesting to study task-technology fit's (Goodhue and Thompson, 1995) explanatory power on work engagement among knowledge workers in the digital work platform context. Finally, studying differences between freelancers carrying out autonomous or interdependent work tasks and comparing the antecedents leading to their work engagement would be another interesting research idea.

\section{Conclusions}

Our analyses indicate that the model fit statistics are at a convincing level and that all three relationships tested are statistically significant and positive. There seems to be evidence of the importance of both virtual community trust and work engagement to person-job fit in the context of virtual knowledge work. This indicates that also in virtual knowledge work the effect of trust to person-job fit and both the direct and the indirect effect of work engagement on person-job fit are crucial. The implications of our research findings emphasize the importance of trust in the development of both work engagement and person-job 
fit. In addition, work engagement further strengthens this relationship. Based on our research we recommend that Usoro et al.'s (2007) Virtual community trust measure can be used in further studies on freelancing. We believe that researchers on trust have an opportunity to contribute to the research and practice of the changing nature of knowledge work and its new forms of organizing such as freelancing on digital work platforms. 


\section{References}

Agarwal, U. (2014), "Linking justice, trust and innovative work behaviour to work engagement", Personnel Review. Vol. 43 No. 1, pp. 41-73.

Aguinis, H. and Lawal, S. O. (2013), “eLancing: A review and research agenda for bridging the sciencepractice gap", Human Resource Management Review, .Vol. 23, pp. 6-17.

Bakker, A. B., Albrecht, S. L. and Leiter, M. P. (2011), "Work engagement: Further reflections of the state of play", European Journal of Work and Organizational Psychology, Vol. 20 No. 1, pp. 74-88.

Blomqvist, K. (1997), “The Many Faces of Trust”, Scandinavian Journal of Management. Vol. 13 No. 3, pp. 271-286.

Caballer, A., Gracia, F. and Peiró, J-M. (2016), “Affective responses to work process and outcomes in virtual teams. Effects of communication media and time pressure", Journal of Managerial Psychology, Vol. 20 No. 3/4, pp. 245-260.

Cable, D. M. and Judge, T. A. (1996), "Person organization fit, job choice decisions, and organizational entry”, Organizational Behavior and Human Decision Processes, Vol. 67, pp. 294-311.

Chen, C. J. and Hung, S. W. (2010), “To give or to receive? Factors influencing members' knowledge sharing and community promotion in professional virtual communities", Information and Management. Vol. 47 No. 4, pp. 226-236.

Chi, N. W. and Pan, S. Y. (2012), “A multilevel investigation of missing links between transformational leadership and task performance: The mediating roles of perceived person-job fit and personorganization fit", Journal of Business and Psychology, Vol. 27 No. 1, pp. 43-56.

Christian, M. S., Garza, A. S., and Slaughter, J. E. (2011), "Work engagement: A quantitative review and test of its relations with task and contextual performance", Personnel Psychology, Vol. 64, pp. 89136.

Chucktai, A. A. and Buckley, F. (2008), "Work Engagement and its Relationship with State and Trait Trust: A Conceptual Analysis", Journal of Behavioral and Applied Management, Vol. 10 No. 1, pp. 4771.

Colbert, A., Yee, N. and George, G. (2016), "The digital workforce and the workplace of the future", Academy of Management Journal, Vol. 59, pp. 731-739.

Davenport, T. H., Thomas, R. J., Cantrell, S. and De Long, D. W. (2002), “The art of work: Facilitating the effectiveness of high-end knowledge workers", Accenture Institute for Strategic Change, Vol. 2.

Demerouti, E., Bakker, A. B., Nachreiner, F. and Schaufeli, W. B. (2001), "The Job Demands-Resources Model of Burnout”, Journal of Applied Psychology, Vol. 86 No. 3, pp. 499-512.

Dirks, K. T. (1999), “The effects of interpersonal trust on work group performance”, Journal of Applied Psychology, Vol. 84 No. 3, pp. 445-455.

Dirks, K. T. and Ferrin, D. L. (2001), "The role of trust in organizational settings", Organization Science. Vol. 12 No. 4, pp. 450-467. 
Dul, J., Ceylan, C. and Jaspers, F. (2011), "Knowledge workers' creativity and the role of the physical work environment", Human Resource Management, Vol. 50 No. 6, pp. 715-734.

Edwards, J. R. (2008), "Person-Environment Fit in Organizations: An Assessment of Theoretical Progress", The Academy of Management Annals, Vol. 2 No. 1, pp. 167-230.

Faraj, S., von Krogh, G., Monteiro, E. and Lakhani, K. R. (2016), "Special Section Introduction - Online Community as Space for Knowledge Flows", Information Systems Research, Vol. 27 No. 4, pp. 668684.

García-Herrero, S., Mariscal, M. A., Gutiérrez, J. M. and Ritzel, D. O. (2013), "Using Bayesian networks to analyze occupational stress caused by work demands: Preventing stress through social support", Accident Analysis and Prevention, Vol. 57, pp. 114-123.

Goodhue, D. L. (1998), "Development and measurement validity of a task-technology fit instrument for user evaluations of information system”, Decision sciences, Vol. 29 No. 1, pp. 105-138.

Goodhue, D. L. and Thompson, R. L. (1995), "Task-technology fit and individual performance. Management Information Systems Quarterly, June, pp. 213-236.

Hallberg, U. and Schaufeli, W. B. (2006), "Same Same" But Different? Can Work Engagement Be Discriminated from Job Involvement and Organizational Commitment?", European Psychologist, Vol. 11 No. 2, pp. 119-127.

Heaphy, E. D., Byron, K., Ballinger, G. A., Gittell, J. H., Leana, C. and Sluss, D. M. (2018), "Introduction to Special Topic Forum: The Changing Nature of Work Relationships", Academy of Management Review, Vol. 43 No. 4, pp. 558-569.

Heggestad, E. D., Scheaf, D. J., Banks, G. C., Monroe Hausfeld, M., Tonidandel, S. and Williams, E. B. (2019), "Scale Adaptation in Organizational Science Research: A Review and Best-Practice Recommendations", Journal of Management, available online https://doi.org/10.1177/0149206319850280

Hsu, C.-P., Chiang, Y.-F. and Huang, H.-C. (2012), "How experience-driven community identification generates trust and engagement", Online Information Review, Vol. 36 No. 1, pp. 72-88.

Hsu, M.-H., Ju, T. L., Yen, C.-H. and Chang, C. M. (2007), "Knowledge sharing behavior in virtual communities: The relationship between trust, self-efficacy, and outcome expectations", International Journal of Human-computer Studies, Vol. 65 No. 2, pp. 153-169.

Kahn, W. A. (1992), “To Be Fully There: Psychological Presence at Work”, Human Relations, Vol. 45 No. 4, pp. 321-349.

Kahn, W. A. (1990), "Psychological conditions of personal engagement and disengagement at work", Academy of Management Journal, Vol. 33 No. 4, pp. 692-724.

Kane, G. C., Palmer, D., Nguyen Phillips, A., Kiron, D. and Buckley, N. (2016), "Aligning the Organization for Its Digital Future. Findings from the 2016 Digital Business Global Executive Study and Research Project", MITSloan Management Review, Research Report, Summer. 
Kelliher, C. and Richardson, J. (Eds.) (2011), "New ways of organizing work. Developments, Perspectives, and Experiences". New York: Routledge.

Kenney, M. and Zysman, J. (2016), "The Rise of the Platform Economy", Issues in Science and Technology, Vol. 32 No. 3, pp. 61-69.

Kosonen, M. (2009), "Knowledge sharing in virtual communities - a review of the empirical research", International Journal of Web Based Communities, Vol. 5 No. 2, pp. 144-163.

Kosonen, M., Blomqvist, K. and Ellonen, R. (2008), “Trust and Its Impersonal Nature”, In: Putnik, G. D. and Cunha, M. M. (Eds.), Encyclopedia of Networked and Virtual Organizations, Vol. 1. Hershey, PA: IGI Global, pp. 1683-1690.

Kristof-Brown, A. L., Zimmerman, R. D and Johnson, E. C. (2005), “Consequences of individuals' fit at work. A meta-analysis of person-job, person-organization, person-group, and person-supervisor fit", Personnel Psychology, Vol. 58, pp. 281-342.

Latham, G. P. and Pinder, G. C. (2005) "Work Motivation Theory and Research at the Dawn of the Twenty-First Century", Annual Review of Psychology, Vol. 56, pp. 485-516.

Lauver, K. J. and Kristof-Brown, A. (2001), "Distinguishing between employees' perceptions of personjob and person-organization fit”, Journal of Vocational Behavior, Vol. 59, pp. 454-470.

Macey, W. H. and Schneider, B. (2008), "The Meaning of Employee Engagement", Industrial and Organizational Psychology, Vol. 1, pp. 3-30.

Majewski, G., Usoro, A. and Khan, I. (2011), "Knowledge sharing in immersive virtual communities of practice" Vine Journal of Information and Knowledge Management systems, Vol. 41 No. 1, pp. 41-62.

May, D. R., Gilson, R. L., and Harter, L. M. (2004), "The psychological conditions of meaningfulness, safety and availability and the engagement of the human spirit at work", Journal of Occupational and Organizational Psychology, Vol. 77, pp. 11-37.

Mayer, R. C., Davis, J. H. and Schoorman, F. D. (1995), “An integrative model of organizational trust”, Academy of Management Review, Vol. 20 No. 3, pp. 709-734.

McKnight, D. H., Choudhury, V. and Kacmar, C. (2002), "Developing and validating trust measures for e-commerce: An integrative typology”, Information Systems Research, Vol. 13 No. 3, pp. 334-359.

Mäkikangas, A., Schaufeli, W., Tolvanen, A. and Feldt, T. (2013), "Engaged managers are not workaholics: Evidence from a longitudinal person-centered analysis", Journal of Work and Organizational Psychology, Vol. 29, pp. 135-143.

Nickols, F. R. E. D. (2000), "What Is in the World of Work and Working. Some Implications of the Shift to Knowledge Work", The knowledge management yearbook 2001, pp. 3-11.

Oldham, G. (1975), "The impact of supervisory characteristics on goal acceptance", Academy of Management Journal, Vol. 18, pp. 461-475. 
Resick, C. J., Baltes, B. B., and Shantz, C. W. (2007), "Person-Organization Fit and Work-Related Attitudes and Decisions: Examining Interactive Effects With Job Fit and Conscientiousness", Journal of Applied Psychology, Vol. 92 No. 5, pp. 1446-1455.

Rich, B. L., Lepine, J. A., and Crawford, E. R. (2010). Job engagement: Antecedents and effects on job performance. Academy of Management Journal, Vol. 53:3, pp. 617-635.

Rich, G. (1997), "The sales manager as a role model: Effects on trust, job satisfaction and performance of salespeople", Journal of the Academy of Marketing Science, Vol. 25, pp. 319-328.

Ridings, C., Gefen, D. and Arinze, B. (2002), "Some antecedents and effects of trust in virtual communities", Journal of Strategic Information Systems, Vol. 11, pp. 271-295.

Saks, A. M. and Gruman, J. A. (2014), “What Do We Really Know About Employee Engagement?", Human Resource Development Quarterly, Vol. 25 No. 2, pp. 155-182.

Schaufeli, W. and Salanova, M. (2007), "Work Engagement An Emerging Psychological Concept and Its Implications for Organizations", In: Gilliland, S. W., Steiner, D. D. and Skarlicki, D. P. (Eds.) Managing Social and Ethical Issues in Organizations, Greenwich, Connecticut: Information Age Publishing, pp. 135-177.

Schaufeli, W. B., Bakker, A. B. and Salanova, M. (2006), "The Measurement of Work Engagement With a Short Questionnaire", Educational and Psychological Measurement, Vol. 66 No. 4, pp. 701-716.

Schaufeli, W. B., Salanova, M., González-Roma, V. and Bakker, A. B. (2002), "The Measurement of Engagement and Burnout: A Two Sample Confirmatory Factor Analytical Approach", Journal of Happiness Studies, Vol. 3, pp. 71-92.

Sekiguchi, T. (2004), "Person-organization fit and person-job fit in employee selection: A review of the literature", Osaka keidai ronshu, Vol. 54 No. 6, pp. 179-196.

Seligman, E. P. and Csikszentmihalyi, M. (2000), "Positive Psychology An Introduction", American Psychologist, Vol. 55 No. 1, pp. 5-14.

Sharkie, R. (2009), "Trust in leadership is vital for employee performance", Management Research News, Vol. 32 No. 5, pp. 491-498.

Shuck, B., Reio, T. G. Jr, and Rocco, T. S. (2011), "Employee engagement: an examination of antecedent and outcome variables", Human Resource Development International, Vol. 14 No. 4, pp. 427-445.

Siebert, S., Martin, G., and Bozic, B. (2016), "Research into employee trust: epistemological foundations and paradigmatic boundaries", Human Resource Management Journal, Vol. 26 No. 3, pp. 269-284.

Sortheix, F. M., Chow, A., and Salmela-Aro, K. (2015), "Work values and the transition to work life: A longitudinal study", Journal of Vocational Behavior, Vol. 89, pp. 162-171.

Spinuzzi, C. (2012), "Working Alone Together: Coworking as Emergent Collaborative Activity", Journal of Business and Technical Communication, Vol. 26 No. 4, pp. 399-441. 
Spreitzer, G. M., Cameron, L. and Garrett, L. (2017), “Alternative work arrangements: Two images of the new world of work", Annual Review of Organizational Psychology and Organizational Behavior, Vol. 4, pp. 473-499.

Steger, M. F., Dik, B. J. and Duffy, R. D. (2012), "Measuring meaningful work: The work and meaning inventory (WAMI)", Journal of Career Assessment, Vol. 20 No. 3, pp. 322-337.

Sullivan, S. E., Forret, M. L., Mainiero, L. A. and Terjesen, S. (2007), "What Motivates Entrepreneurs? An Exploratory Study of the Kaleidoscope Career Model and Entrepreneurship", Journal of Applied Management and Entrepreneurship, Vol. 12 No. 4, pp. 4-19.

Süß, S. and Becker, J. (2013), "Competences as the foundation of employability: a qualitative study of German freelancers", Personnel Review, Vol. 42 No. 2, pp. 223-240.

Tims, M. and Bakker, A. B. (2010), “Job crafting: Towards a new model of individual job redesign”, $S A$ Journal of Industrial Psychology, Vol. 36 No. 2, pp. 1-9.

Turner, T. and Pennington, W. W. (2015), "Organizational networks and the process of corporate entrepreneurship: how the motivation, opportunity, and ability to act affect firm knowledge, learning, and innovation", Small Business Economics, Vol. 45, pp. 447-463.

Usoro, A., Sharrat, M. W., Tsui, E. and Shekhar, S. (2007), “Trust as an antecedent to knowledge sharing in virtual communities of practice", Knowledge Management Research and Practice, Vol. 5, pp. 199212.

van Beek, I., Hu, Q., Schaufeli, W. B., Taris, T. W. and Schreurs, B. H. J. (2012), "For Fun, Love, or Money: What Drives Workaholic, Engaged, and Burned-Out Employees at Work?", Applied Psychology: An International Review, Vol. 61 No. 1, pp. 30-55.

Van den Born, A. and Van Witteloostuijn, A. (2013), "Drivers of freelance career success", Journal of Organizational Behavior, Vol. 34, pp. 24-46.

Wu, C.-H., Kao, S.-C. and Shih, C.-H. (2018), "Task-technology fit in knowledge creation: the moderating role of cognitive style", VINE Journal of Information and Knowledge Management, Vol. 48 No. 1, pp. 83-102. 
$<<<$ Please insert Appendix 1 about here $>>>$ 
Figure 1. The Research Model 
Table 1

Results of the confirmatory factor analysis

\begin{tabular}{|c|c|c|c|c|c|c|}
\hline 2 & & Mean & $\begin{array}{c}\text { Std. } \\
\text { deviation }\end{array}$ & $\begin{array}{l}\text { Std. } \\
\text { loading }\end{array}$ & $\mathrm{CR}$ & AVE \\
\hline \multicolumn{7}{|c|}{ Work engagement } \\
\hline \multirow[t]{2}{*}{ Vigor } & At my work, I feel bursting with energy. & 5,228 & 1,170 & 0,810 & 0,891 & 0,805 \\
\hline & At my job, I feel strong and vigorous. & 5,496 & 1,112 & 0,976 & & \\
\hline \multirow[t]{2}{*}{ Dedication } & I am enthusiastic about my job. & 5,953 & 1,022 & 0,839 & 0,767 & 0,623 \\
\hline & I am proud of the work that I do. & 6,173 & 0,969 & 0,736 & & \\
\hline \multirow[t]{2}{*}{ Absorption } & I am immersed in my work. & 5,409 & 1,243 & 0,985 & 0,818 & 0,700 \\
\hline & I get carried away when I'm working. & 5,425 & 1,294 & 0,655 & & \\
\hline \multicolumn{7}{|l|}{ Person-job fit } \\
\hline & $\begin{array}{l}\text { To what extent ... does your work fit with your } \\
\text { expectations? }\end{array}$ & 5,535 & 1,332 & 0,839 & 0,928 & 0,762 \\
\hline & ... does your work suit you? & 5,701 & 1,323 & 0,841 & & \\
\hline & $\begin{array}{l}\ldots \text { does your work enable you to work in } \\
\text { assignments you want to work in? }\end{array}$ & 5,512 & 1,309 & 0,902 & & \\
\hline & ... does doing your work match your career plans? & 5,433 & 1,472 & 0,907 & & \\
\hline \multicolumn{7}{|c|}{ Virtual community trust } \\
\hline \multirow[t]{3}{*}{ Benevolence } & $\begin{array}{l}\text { I believe that the XYZ's virtual community would } \\
\text { act in my best interest. }\end{array}$ & 5,221 & 1,362 & 0,880 & 0,913 & 0,778 \\
\hline & $\begin{array}{l}\text { If I required help, the community would do its best } \\
\text { to help me. }\end{array}$ & 5,158 & 1,359 & 0,937 & & \\
\hline & $\begin{array}{l}\text { The community is interested in my well-being, not } \\
\text { just its own. }\end{array}$ & 4,764 & 1,433 & 0,825 & & \\
\hline \multirow[t]{3}{*}{ Integrity } & I would characterize the community as honest. & 5,472 & 1,233 & 0,924 & 0,950 & 0,863 \\
\hline & The community would keep its commitments. & 5,331 & 1,316 & 0,913 & & \\
\hline & The community is genuine and sincere. & 4,409 & 1,230 & 0,950 & & \\
\hline \multirow[t]{3}{*}{ Competence } & $\begin{array}{l}\text { The community is a competent and effective source } \\
\text { of expertise. }\end{array}$ & & 1,362 & 0,967 & 0,933 & 0,822 \\
\hline & $\begin{array}{l}\text { The community performs its role of sharing } \\
\text { knowledge very well. }\end{array}$ & 5,189 & 1,379 & 0,884 & & \\
\hline & In general, the community is very knowledgeable. & 5,457 & 1,457 & 0,867 & & \\
\hline \multicolumn{7}{|c|}{ Model fit: $\chi 2=191.66, \mathrm{df}=131, \mathrm{RMSEA}=0.061, \mathrm{NFI}=0.955, \mathrm{NNFI}=0.973$} \\
\hline
\end{tabular}




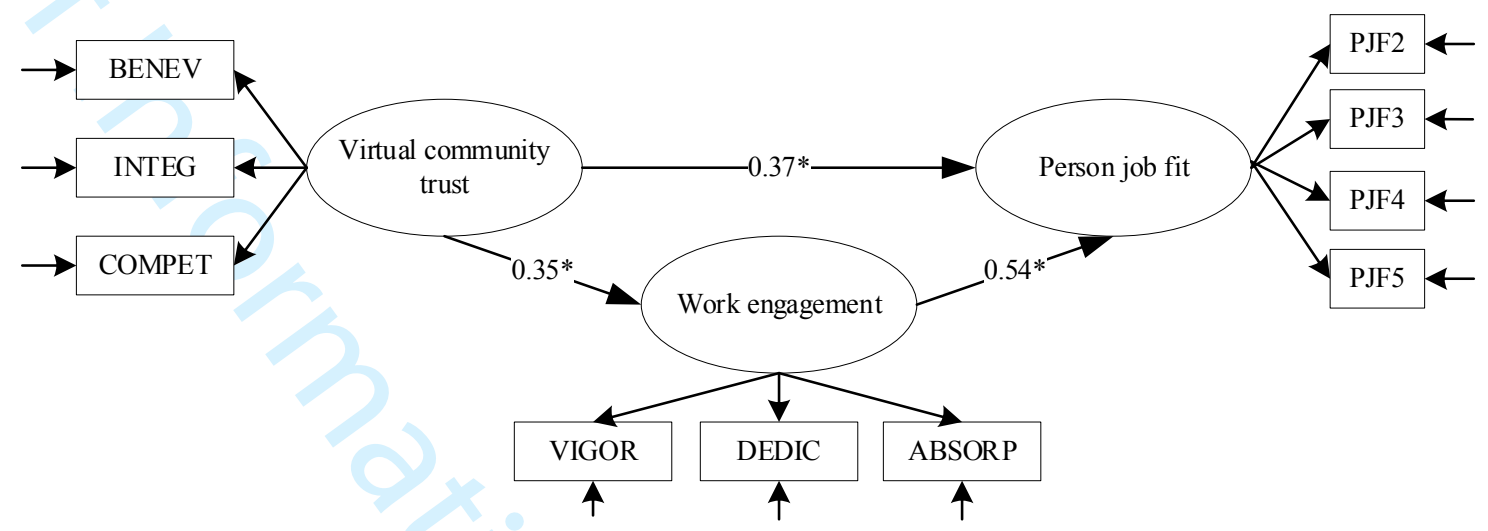

Figure 2. The Results of the Modelling ( $\left.{ }^{*} p<0.001\right)$ 


\section{Appendix 1}

\section{Virtual community trust (Usoro et al., 2007)}

- benevolence

- Integrity

- Ability

- How would you describe your beliefs about the XYZ community?

- I believe that XYZ's virtual community would act in my best interest.

- If I required help, the community would do its best to help me.

- The community is interested in my well-being, not just its own.

- The community is truthful in its dealings with me.

- I would characterise the community as honest.

- The community would keep its commitments.

- The community is genuine and sincere.

- The community is a competent and effective source of expertise.

- The community performs its role of sharing knowledge very well.

- Overall, the community is a capable and proficient source of expertise and knowledge.

- In general, the community is very knowledgeable.

- I trust the community when I ask them not to forward or share any sensitive material.

Work engagement (Schaufeli et al., 2006)

- At my work, I feel bursting with energy.

- At my job, I feel strong and vigorous.

- I am enthusiastic about my job.

- My job inspires me.

- When I get up in the morning, I feel like going to work.

- I feel happy when I am working intensely.

- I am proud of the work that I do.

- I am immersed in my work.

- I get carried away when I'm working.

\section{Person-job fit (Kristof-Brown et al., 2005)}

- To what extent do your knowledge, skills and abilities match the requirements of working in the XYZ's projects?

- To what extent does working in the XYZ's projects fit with your expectations?

- To what extent does working in the XYZ's projects suit you?

- To what extent does working in the XYZ's projects enable you to work in assignments you want to work in?

- To what extent does working in the XYZ's projects match your future career plans? 